\title{
Control of Arginine Biosynthesis in Pseudomonas aeruginosa
}

\author{
By JILLIAN H. ISAAC AND B. W. HOLLOWAY \\ Department of Genetics, Monash University, \\ Clayton, Victoria 3I68, Australia
}

(Received 20 December I97I; revised 4 July 1972)

\begin{abstract}
SUMMARY
Arginine biosynthesis in Pseudomonas aeruginosa proceeded via transacetylation of acetylornithine with glutamate; it resembled Micrococcus glutamicus rather than Escherichia coli. Of four arginine biosynthetic enzymes, $N$-acetyl- $\gamma$-glutamokinase, $\mathrm{N}$-acetylornithine glutamate transacetylase, ornithine transcarbamylase and argininosuccinase determined under various conditions of arginine excess and deprivation, only ornithine transcarbamylase (OTCase) varied. It appeared to be fully derepressed in the wild-type strain grown in minimal medium and partially repressed in the presence of arginine. OTCase was also partially repressed in all arginine auxotrophs, even when deprived of arginine. OTCase was derepressed in bradytrophic revertants of arginine auxotrophs grown in minimal medium, but its level was never greater than that in the wild-type. The level of endogenous arginine in the wild-type strain grown in minimal medium is probably insufficient to effect repression. Exogenous arginine is more effective in repression when present as the sole carbon source.
\end{abstract}

\section{INTRODUCTION}

Arginine biosynthetic pathways differ amongst various micro-organisms in the actual biosynthetic sequence, the mechanisms of control and in the arrangement of genetic loci. In those bacteria studied, arginine synthesis proceeds via ornithine and citrulline. Micrococcus glutamicus and several other bacterial species, including Pseudomonas fluorescens, synthesize ornithine by transacetylation of acetylornithine and glutamate (Udaka \& Kinoshita, I958; Udaka, 1966), in contrast to the hydrolysis of acetylornithine which occurs in ornithine synthesis in Escherichia coli (Vogel \& Bonner, 1956), Proteus mirabilis (Prozesky, 1967), Serratia marcescens and certain other enteric bacteria (Udaka, 1966).

Udaka's (I966) survey demonstrated that, in those organisms which produced ornithine by transacetylation, the second enzyme, $N$-acetyl- $\gamma$-glutamokinase, was subject to feedback inhibition by arginine, whereas the first enzyme, $N$-acetylglutamate synthetase, was inhibited by arginine in those organisms producing ornithine by direct hydrolysis of acetylornithine.

Pathway-wide variation of arginine biosynthetic enzyme levels under different conditions of arginine availability occurs in Escherichia coli strains KI2 and W (Maas, I96I; Vogel, Bacon \& Baich, 1963; Baumberg, Bacon \& Vogel, 1965) and in Proteus mirabilis (Prozesky, I969). Exogenous arginine decreases enzyme levels of $E$. coli strains KI 2 and w, but induces slightly in E. coli в (Gorini \& Gunderson, 196I); mutation in a regulatory gene changes this induction response to the repressible phenotype of E. coli KI 2 (Jacoby \& Gorini, I967). In Saccharomyces cerevesiae, of the several enzymes examined, only ornithine transcarbamylase levels vary in response to arginine excess or deprivation (Middelhoven, 1969).

To date, no instances of comparable pathway-wide variations in enzyme levels have been demonstrated in Pseudomonas. For the tryptophan pathway in Pseudomonas putida induction of two enzymes, repression of three other enzymes and constitutivity of the remaining 
enzyme occurs (Crawford \& Gunsalus, I966). In P. aeruginosa, four of the six enzymes involved in pyrimidine synthesis appear to be constitutive (Isaac \& Holloway, 1968) as are three of the five isoleucine-valine biosynthetic enzymes (Marinus \& Loutit, 1969). Ornithine transcarbamylase, one of the enzymes of the arginine biosynthetic sequence has been reported to be $60 \%$ repressed by exogenous arginine in both $P$. fluorescens and $P$. aeruginosa (Stalon, Ramos, Piérard \& Wiame, 1967).

We have here investigated the factors affecting repressibility of ornithine transcarbamylase in Pseudomonas aeruginosa and their effect on the levels of $\mathrm{N}$-acetyl- $\gamma$-glutamokinase, $\mathrm{N}$ acetylornithine glutamate transacetylase and argininosuccinase. A complicating factor in any investigation of the regulation of arginine biosynthesis in Pseudomonas is that some strains use arginine as a carbon source. An ornithine transcarbamylase in $P$. aeruginosa and $P$. putida, which is not functional in biosynthesis in vivo and is induced by arginine, has been demonstrated (Stalon et al. 1967). A preliminary characterization of the inducibility and properties of this enzyme was therefore necessary.

Feary, Williams, Calhoun \& Walker (1969) demonstrated seven transduction groups of arginine auxotrophs of Pseudomonas aeruginosa indicating a lack of close linkage of these arginine loci. We also report a similar analysis accompanied by identification of the enzymatic lesion for some transduction groups.

\section{METHODS}

Bacteria. The organisms used were derived from Pseudomonas aeruginosa Pao (Holloway, 1969). The prototroph wild-type has the strain number PAOI (ATCC I5692). The various arginine requiring auxotrophs are listed in Table I. PAOI 20 is a bradytroph derived from the uracil-requiring mutant PAOII9 (Isaac \& Holloway, I968).

Bacteriophage. The transducing phage Fi 6 (Holloway, Egan \& Monk, 1960) was used.

Liquid media. Citrate minimal medium (CMM) was modified from Medium $\mathrm{E}$ of Vogel \& Bonner (1956) containing ro mM-citrate as carbon source without addition of glucose because Pseudomonas aeruginosa preferentially uses citrate as carbon source (Hamilton \& Dawes, I959). This concentration of citrate did not limit the growth rate and allowed exponential growth to $5 \times 10^{8}$ organisms $/ \mathrm{ml}$. Arginine minimal medium (AMM) contained $(\mathrm{w} / \mathrm{v}): 0.63 \% \mathrm{~K}_{2} \mathrm{HPO}_{4}, 0.19 \% \mathrm{KH}_{2} \mathrm{PO}_{4}, 0.05 \%\left(\mathrm{NH}_{4}\right)_{2} \mathrm{SO}_{4}, 0.005 \% \mathrm{MgSO}_{4} \cdot 7 \mathrm{H}_{2} \mathrm{O}$ and for various experiments between Io and $40 \mathrm{~mm}$-arginine. Nutrient Yeast Broth (NYB) contained $2.5 \%$ Oxoid Nutrient Broth no. 2 and $0.5 \%$ Oxoid Yeast Extract. Heart Infusion Broth (HIB) contained 2.5\% Difco dehydrated Heart Infusion Broth.

Solid media. Nutrient Agar (MIA) contained 4\% Oxoid Blood Agar Base and $0.5 \%$ Oxoid Yeast Extract. For Minimal Agar (CMA), CMM was solidified with $\mathrm{I} \cdot 2 \%(\mathrm{w} / \mathrm{v})$ Oxoid Agar no. I.

Chemicals. $N$-methyl- $N^{\prime}$-nitro-nitrosoguanidine (NG) was from Aldrich Chemical Co. Milwaukee, Wisconsin, U.S.A.; ethyl methane sulphonate (EMS) from Eastman Organic Chemicals, Rochester, N.Y., U.S.A.; carbamyl phosphate from Calbiochem, San Diego, California, U.S.A.; acetyl phosphate from Boehringer Chemical Co. Mannheim, Germany, and all the other biochemicals were from Sigma Chemical Co, St Louis, Missouri, U.S.A.

Isolation of mutants. Arginine auxotrophs were isolated from strain PAOI as previously described for pyrimidine auxotrophs (Isaac \& Holloway, 1968). Arginine bradytrophs are revertants of arginine auxotrophs and have a growth rate specifically limited by arginine availability (Novick \& Maas, 196I). These were isolated as spontaneous, or EMS-induced (Fargie \& Holloway, 1965) revertants of arginine auxotrophs. Bradytrophs were identified 
by their mean generation time in CMM and in CMM supplemented with I mM-arginine. Those mutants which were taken to be bradytrophs had a mean generation time of $55 \mathrm{~min}$ in arginine-supplemented CMM, and mean generation times in CMM varying from 100 to 720 min. The mean generation time of the wild-type PAOI in CMM was $55 \mathrm{~min}$. The growth temperature of all cultures in this study was $37^{\circ} \mathrm{C}$.

Mean generation times. These were obtained from the logarithmic phase of growth curves of $20 \mathrm{ml}$ cultures shaken in $150 \mathrm{ml}$ flasks carrying Klett-Summerson colorimeter tubes as side arms. Culture densities were determined periodically using a Klett-Summerson Photoelectric colorimeter Model 900-3 (filter no. 54).

Preparation of bacterial extracts. Organisms were grown in $500 \mathrm{ml}$ cultures in 21 baffled flasks shaken on a New Brunswick Gyrotory shaker. Growth curves showed that the conditions used were not oxygen limiting. Following inoculation to $5 \times 1 \mathrm{I}^{3}$ organisms $/ \mathrm{ml}$, growth proceeded overnight and the cultures were harvested in exponential phase at between 60 and 90 Klett units $\left(\mathrm{I} \cdot 5\right.$ to $2 \cdot 5 \times 10^{8}$ organisms $/ \mathrm{ml}$ ). At harvesting, the cultures were cooled by rotating the flasks in ice for several minutes to help maintain as much of the cell mass as possible in exponential phase. Possible leakage of cells due to cold shock did not seem to be of consequence. The cells were sedimented at $13000 \mathrm{~g}$ for $20 \mathrm{~min}$, washed in $0.5 \mathrm{vol}$. of the original culture $0 . \mathrm{I} \mathrm{M}$-tris- $\mathrm{HCl}$ buffer, $\mathrm{pH} 7.5$, and resuspended in $5 \mathrm{ml}$ buffer/g wet wt. Bacteria were disrupted using a French Press operated at $20000 \mathrm{lb} / \mathrm{in}^{2}$. This resulted in a reproducible $95 \%$ loss of viability. Debris was removed at $13000 \mathrm{~g}$ for $30 \mathrm{~min}$ yielding a bacteria-free extract containing 5 to $8 \mathrm{mg}$ protein $/ \mathrm{ml}$.

Determination of exogenous arginine. Residual arginine in culture fluid after harvesting was assayed microbiologically using an arginine auxotroph.

\section{Enzyme assays}

All incubations were at $37{ }^{\circ} \mathrm{C} ; \mathrm{pH}$ values quoted to this temperature.

$N$-Acetyl- $\gamma$-glutamokinase (ATP: N-acetylglutamate 5-phosphotransferase). $N$-Acetylglutamyl hydroxamate formation was measured using the reaction of $\mathrm{FeCl}_{3}$ with hydroxamates (Baich \& Vogel, I962). The $\mathrm{pH}$ optimum for this enzyme in Pseudomonas aeruginosa was $9 \cdot 0$. Acetylglutamate ( $40 \mathrm{~mm}$ ), ATP (IO mM), $\mathrm{MgCl}_{2}$ (IO mM), neutralized $\mathrm{NH}_{2} \mathrm{OH}$. $\mathrm{HCl}$ $(0.4 \mathrm{M})$ and tris- $\mathrm{HCl}(\mathrm{I} 00 \mathrm{mM}), \mathrm{pH} 9.0$, were incubated for $30 \mathrm{~min}$ with $0.2 \mathrm{mg}$ protein $/ \mathrm{ml}$. The reaction was stopped by $\mathrm{I} \cdot 0 \mathrm{ml}$ or $10 \%$ trichloracetic acid followed by $2 \cdot 0 \mathrm{ml}$ of $5 \% \mathrm{FeCl}_{3} \cdot 6 \mathrm{H}_{2} \mathrm{O}$ in $\mathrm{I} \mathrm{M}-\mathrm{HCl}$. Precipitated protein was removed by filtration and absorbance read at $540 \mathrm{~nm}$. Since the response produced by acetylglutamyl phosphate is almost the same as that for acetyl phosphate (Udaka, I966), a standard curve with o to $4 \cdot 0 \mu \mathrm{mol}$ acetyl phosphate was used.

$N$-Acetylornithine glutamate transacetylase ( $N$-acetylornithine: L-glutamate $N$-acetyltransferase). This enzyme was assayed according to Udaka \& Kinoshita (1958). N-Acetylornithine (I $\mathrm{mM}$ ), sodium glutamate (neutralized) (5 mM) and phosphate buffer (IOO mM), pH $7 \cdot 0$, were incubated for Io min with sufficient extract (approx. $0.5 \mathrm{mg}$ protein $/ \mathrm{ml}$ ) to produce 0.04 to $0.10 \mu \mathrm{mo}$ ornithine. Ornithine was estimated by a modified ninhydrin determination which is specific for ornithine, proline and lysine (Vogel \& Bonner, 1956) and the absorbance was read at $450 \mathrm{~nm}$ to minimize interference caused by glutamate. A standard curve with o to $0.20 \mu \mathrm{mol}$ ornithine in $100 \mathrm{mM}$-phosphate buffer, $\mathrm{pH} 7 \cdot 0$, was used.

$N$-Acetylornithinase $(\alpha-N$-acetyl L-ornithine amidohydrolase, $E C$. 3.5.I . I6) was assayed according to Vogel \& Bonner (I956) except that incubation was at $\mathrm{pH} 7.5$ instead of 7.0 . Sufficient extract $(0.2$ to $0.4 \mathrm{mg})$ was added to produce 0.02 to $0.10 \mu \mathrm{mol}$ ornithine in 15 to 
$20 \mathrm{~min}$. The standard curve contained 0 to $0.20 \mu \mathrm{mol}$ ornithine in $100 \mathrm{~mm}$-phosphate buffer, $\mathrm{pH} 7 \cdot 5$.

Ornithine transcarbamylase (carbamoyl phosphate: L-ornithine carbamoyl transferase, EC. 2.1.3.3). The biosynthetic activity was measured at the $\mathrm{pH}$ optimum of 8.7 using Io mM-carbamoyl phosphate (dilithium salt), $10 \mathrm{mM}-\mathrm{L}-$ ornithine, Ioo mM-tris- $\mathrm{HCl}, \mathrm{pH} 8 \cdot 7$, and extract containing $0.0 \mathrm{I}$ to $0 . \mathrm{I} 0 \mathrm{mg}$ protein $/ \mathrm{ml}$. The citrulline produced $(0.05$ to 0.20 $\mu \mathrm{mol}$ ) after Io min was estimated by a modification of the method of Archibald (1944). The reaction was stopped by vigorous mixing with $3.0 \mathrm{ml}$ of an aqueous solution containing I0 $\%$ of $\mathrm{H}_{2} \mathrm{SO}_{4}, 30 \%$ of $\mathrm{H}_{3} \mathrm{PO}_{4}$ and $0.15 \%$ of diacetyl monoxime. The colour was developed and read by the method of Archibald except that the mixture was boiled for $30 \mathrm{~min}$. A standard curve with 0 to $0.40 \mu \mathrm{mol}$ citrulline was used.

The activity of the degradative ornithine transcarbamylase was assayed at the $\mathrm{pH}$ optimum of $7 \cdot 5$. This enzyme was activated by phosphate ions, optimal activation occurring at $4 \mathrm{~mm}-\mathrm{KH}_{2} \mathrm{PO}_{4}$. The assay was as above except that the incubation mixture contained Ioo mM-tris- $\mathrm{HCl}, \mathrm{pH} 7 \cdot 5$, and $4 \mathrm{mM}-\mathrm{KH}_{2} \mathrm{PO}_{4}$.

Argininosuccinate synthetase (L-citrulline: L-aspartate ligase, EC. 6.3.4.5) was assayed by the method of Ratner (1955), with citrulline being determined by the method of Archibald (I944).

Argininosuccinase (L-argininosuccinate-arginine lyase, EC. 4.3.2.1) was assayed by the method of Ratner (1955), with several modifications. Arginine deiminase, which results in production of citrulline from arginine was sometimes present, so it was necessary (i) to use the modification of Baumberg et al. (1965) of assaying for ornithine, and (ii) to assay at a $\mathrm{pH}$ which allowed minimal interference of arginine deiminase ( $\mathrm{pH}$ optimum 6). Five mM-sodium argininosuccinate (prepared by treatment of barium argininosuccinate with $\mathrm{Na}_{2} \mathrm{SO}_{4}$ ), I00 mM-tris- $\mathrm{HCl}, \mathrm{pH} 9 \cdot 0,0.45 \mathrm{mg} / \mathrm{ml}$ of arginase (pre-incubated with $0.05 \mathrm{M}-\mathrm{MnCl}_{2}$ at $55^{\circ} \mathrm{C}$ for Io min) and sufficient extract to produce 0.03 to $0.10 \mu \mathrm{mol}$ ornithine $(0.5$ to $\mathrm{I} \cdot 0 \mathrm{mg}$ protein $/ \mathrm{ml})$ were incubated for $\mathrm{I} 5 \mathrm{~min}$. Ornithine was estimated as described above using a standard curve in $100 \mathrm{~mm}$-tris- $\mathrm{HCl}, \mathrm{pH} \mathrm{9.0.}$

The arginase was freshly prepared each day and, concurrent with each assay, was tested for its ability to hydrolyse $5 \mathrm{~mm}$-arginine completely. The arginase activity was measured by estimation of urea using the method for citrulline determination above but reading at $500 \mathrm{~nm}$. Estimation of urea rather than ornithine was necessary because urea responds to the ornithine assay at high concentrations.

Unless otherwise stated, all assays were carried out with saturating substrate concentrations and initial rates of reactions were measured. Controls lacking either enzyme or substrate were included in all assays. Activities are quoted as $\mu \mathrm{mol}$ product formed $/ \mathrm{h} / \mathrm{mg}$ protein.

Protein was estimated by the method of Lowry, Rosebrough, Farr \& Randall (I95I) using bovine serum albumin Fraction $\mathrm{V}$ as standard.

Transduction procedures. These were those used by Isaac \& Holloway (I968).

\section{RESULTS}

Establishment of the arginine biosynthetic pathway in Pseudomonas aeruginosa

Using the method described previously (Isaac \& Holloway, 1968), a series of argininerequiring auxotrophs was isolated. These were tested for their ability to grow on several of the intermediates of the arginine biosynthetic pathway of Escherichia coli (Vogel et al. I963; Albrecht \& Vogel, 1964). These were $N$-acetylglutamate, $N$-acetylornithine, ornithine, 


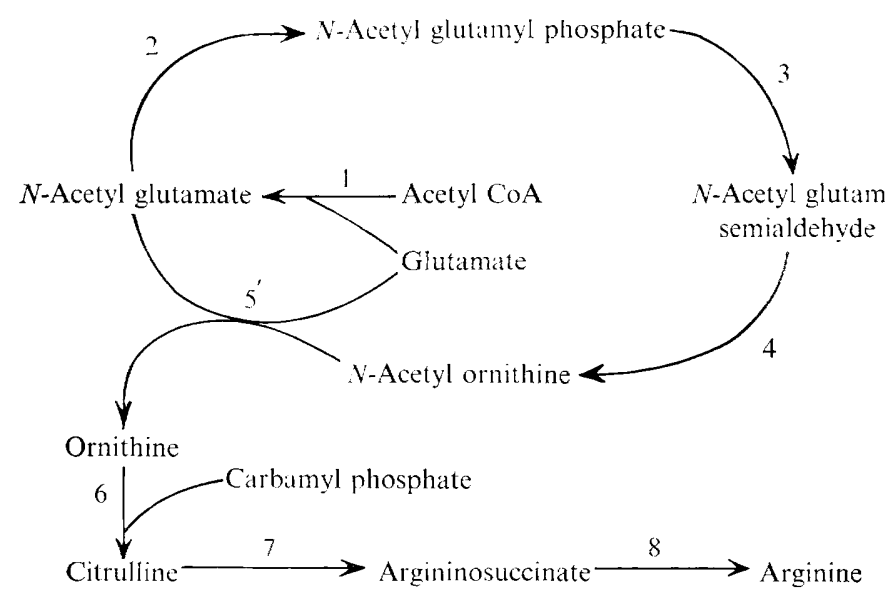

Fig. I. The probable biosynthetic pathway of arginine in Pseudomonas aeruginosa. The numbers refer to enzymatic steps: I, acetylglutamate synthetase; $2, N$-acetyl- $\gamma$-glutamokinase; $3, N$-acetylglutamic- $\gamma$-semialdehyde dehydrogenase; 4, N-acetylornithine- $\delta$-transaminase; $5^{\prime}, N$-acetylornithine-glutamate transacetylase; 6 , ornithine transcarbamylase; 7 , argininosuccinate synthetase; 8 , argininosuccinase.

citrulline, barium argininosuccinate and arginine. The only substances eliciting a growth response from any auxotroph in media with a $\mathrm{pH}$ range of 5.0 to $7^{\circ} 0$ were ornithine, citrulline and arginine. On this basis the mutants could be divided into three groups: those blocked before ornithine, those blocked between ornithine and citrulline, and those blocked between citrulline and arginine. It can therefore be inferred that in Pseudomonas aeruginosa the biosynthesis of arginine proceeds via ornithine and citrulline.

Cell-free extracts of the wild-type were examined for activity of several enzymes involved in arginine biosynthesis in other organisms. Under the assay conditions described above, activity of $N$-acetyl- $\gamma$-glutamokinase (enzyme 2), $N$-acetylornithine glutamate transacetylase (enzyme $5^{\prime}$ ), ornithine transcarbamylase (OTCase, enzyme 6), argininosuccinate synthetase (enzyme 7) and argininosuccinase (enzyme 8) could be demonstrated in wild-type organisms grown in CMM. Significant activity of $N$-acetylornithinase (enzyme 5) could only be demonstrated in organisms grown in the presence of arginine.

The three groups of auxotrophs identified by their growth responses were further classified on the basis of absence of enzymes demonstrated in the wild-type. Those mutants which responded to arginine but not to citrulline were divided into two groups, viz. those lacking argininosuccinate synthetase (PAO305, PAO309, PAO3I 2, PAO3I5, PAO367, PAO374) and those lacking argininosuccinase (PAO297, PAO3I4, PAO362, PAO365, PAO370). As expected, the mutant PAO317, which responded to citrulline and arginine but not to ornithine, lacked ornithine transcarbamylase activity. No mutants lacked activity of $N$-acetyl- $\gamma$-glutamokinase or $N$-acetylornithine glutamate transacetylase so that the mutants blocked before ornithine (PAO296, PAO298, PAO303, PAO307, PAO3II, PAO364, PAO366) must have a lesion in production of one of the enzymes 1,3 or 4 . Neither cross-feeding between these auxotrophs blocked before ornithine, nor a growth response to $N$-acetyl- $\gamma$-glutamate or $N$-acetylornithine could be demonstrated. 


\section{Table I. Transduction analysis of arginine auxotrophs}

The transducing phage FII 6 was propagated on the various donor strains, and individual transductions standardized in terms of the phage titre, density and growth conditions of the recipient strains, and transduction ability of the individual phage preparations in terms of a common auxotrophic recipient. $+=$ A frequency of prototroph formation similar to that found with PAOI as a donor, $-=$ the absence of prototroph formation.

\begin{tabular}{|c|c|c|c|c|c|c|}
\hline \multirow[b]{2}{*}{$\begin{array}{l}\text { Recipient } \\
\text { strains }\end{array}$} & \multicolumn{6}{|c|}{ Recipient strains } \\
\hline & 307,3 I I & $\begin{array}{r}298,303, \\
364,296\end{array}$ & 366 & 317 & $\begin{array}{l}315,305, \\
309,312, \\
367,374\end{array}$ & $\begin{array}{c}370,297, \\
362,365, \\
314\end{array}$ \\
\hline 307,311 & - & + & + & + & + & + \\
\hline $298,303,364,296$ & . & - & + & + & + & + \\
\hline 366 & . & . & - & + & + & + \\
\hline 317 & . & . & . & - & + & + \\
\hline $315,305,309,312,367,374$ & . & . & . & . & - & + \\
\hline $370,297,362,365,314$ & . & . & . & . & . & - \\
\hline
\end{tabular}

Table 2. Inhibition of $N$-acetyl- $\gamma$-glutamokinase

Cell-free extracts of PAOI harvested from CMM in exponential phase were assayed for activity of $N$-acetyl- $\gamma$-glutamokinase in the presence of the supplements listed.

$\begin{array}{lcr}\quad \begin{array}{c}\text { Addition to } \\ \text { incubation mixture }\end{array} & \begin{array}{c}\text { Activity } \\ (\mu \mathrm{mol} / \mathrm{h} / \mathrm{mg} \text { protein })\end{array} & \begin{array}{c}\text { Inhibition } \\ (\%)\end{array} \\ \text { Nil } & \mathrm{I} \cdot 3 & 0 \\ \text { Arginine } 1 \mathrm{IO}^{-3} \mathrm{M} & <0 \cdot \mathrm{I} & >90 \\ \text { Arginine } 10^{-4} \mathrm{M} & 0.4 & 80 \\ \text { Arginine } 5 \times 10^{-5} \mathrm{M} & 0.9 & 30 \\ \text { Citrulline } 10^{-3} \mathrm{M} & <0 \cdot \mathrm{I} & >90 \\ \text { Ornithine } 10^{-3} \mathrm{M} & \mathrm{I} \cdot \mathrm{O} & 20\end{array}$

\section{Grouping of mutants by transduction analysis}

Fargie \& Holloway (I965) showed that by transduction with phage FII6, argininerequiring mutants of Pseudomonas aeruginosa strain PAT could be placed into three groups. Subsequently Feary et al. (1969) classified $5 \mathrm{I}$ arginine-requiring mutants of $P$. aeruginosa strain PAO into six transduction groups, while 52 arginine-requiring mutants of $P$. aeruginosa strain 78C (Pearce \& Loutit, 1965) were likewise classified into six transduction groups. Comparison of growth responses of the arginine auxotrophs of these two strains led to the proposal of at least seven transduction groups of arginine auxotrophs in $P$. aeruginosa.

The nineteen mutants of strain PAO used in this present study have been analysed with transducing phage FII 6 and found to fall into six groups. The procedure used has been to grow phage on each mutant as a donor and use each mutant in turn as a recipient. The production of prototrophic colonies at frequencies similar to that obtained when the prototrophic parent strain PAO is used as a donor, indicates genetic heterogenerity of the donor and recipient strains. Six transduction groups were identified by this means (Table $\mathbf{I}$ ). Particular enzymatic lesions can be assigned to three of these transduction groups. The mutants blocked before ornithine can be separated into three groups and as wild-type levels of activity of both $N$-acetyl- $\gamma$-glutamokinase (enzyme 2) and $N$-acetylornithine glutamate transacetylase (enzyme $5^{\prime}$ ) can be demonstrated in all of these mutants, their enzymatic lesions must be in enzymes I, 3 or 4 . These have not been further differentiated. 
Table 3. The effect of exogenous arginine on enzyme levels in the wild-type PAOI and the arginine bradytroph PAOI03I grown on CMM in shaken culture

\begin{tabular}{|c|c|c|c|}
\hline \multirow[b]{2}{*}{ Strain } & \multicolumn{3}{|c|}{$\begin{array}{l}\text { Arginine concentration } \\
\qquad(\mathrm{mM})\end{array}$} \\
\hline & Initial & $\begin{array}{l}\text { Generation } \\
\text { time (min) }\end{array}$ & $\begin{array}{c}\text { At } \\
\text { harvesting }\end{array}$ \\
\hline \multirow[t]{3}{*}{ PAOI } & 0.0 & 55 & $0 \cdot 0$ \\
\hline & $I \cdot O$ & 55 & 0.3 \\
\hline & $5 \cdot 0$ & . & $4 \cdot 5$ \\
\hline \multirow[t]{2}{*}{ PAOIO3I } & $0.0^{*}$ & 280 & . \\
\hline & $1 \cdot 0$ & 55 & . \\
\hline
\end{tabular}

\begin{tabular}{|c|c|c|c|}
\hline \multicolumn{4}{|c|}{$\begin{array}{c}\text { Enzyme activity } \\
(\mu \mathrm{mol} \text { product } / \mathrm{h} / \mathrm{mg} \text { protein })\end{array}$} \\
\hline 2 & $5^{\prime}$ & 6 & 8 \\
\hline$I \cdot 2 \pm 0 \cdot I$ & $2 \cdot 1 \pm 0.2$ & $60 \cdot 0 \pm 4 \cdot 0$ & $I \cdot 3 \pm 0 \cdot 1$ \\
\hline $1 \cdot 3 \pm 0 \cdot 1$ & $2 \cdot 3 \pm 0.2$ & $I 0 \cdot I \pm I \cdot 5$ & $I \cdot 4 \pm 0 \cdot I$ \\
\hline$I \cdot 3 \pm 0 \cdot I$ & $2 \cdot 3 \pm 0.2$ & $10 \cdot 3 \pm \mathrm{I} \cdot 5$ & $\mathrm{I} \cdot 3 \pm 0 \cdot \mathrm{I}$ \\
\hline$I \cdot 3$ & $2 \cdot 3$ & $58 \cdot 0$ & $I \cdot 2$ \\
\hline $1 \cdot 4$ & $2 \cdot 5$ & 12.5 & $I \cdot 2$ \\
\hline
\end{tabular}

* Deprived of arginine for $46 \mathrm{~h}$ (Table 4 ).

\section{Feedback inhibition of $N$-acetyl- $\gamma$-glutamokinase}

Fig. I indicates the probable pathway of biosynthesis of arginine in Pseudomonas aeruginos $a$ with $N$-acetylornithine glutamate transacetylase catalysing the conversion of $N$-acetylornithine to ornithine. This in effect makes $N$-acetyl- $\gamma$-glutamokinase the initiating enzyme of the pathway. The activity of this enzyme is strongly inhibited by arginine and citrulline, and to a lesser extent by ornithine (Table 2).

The importance of the arginine degradative pathway during exponential growth

PAOI grows very efficiently (mean generation time 55 to $60 \mathrm{~min}$ ) on arginine as sole carbon source. Stalon et al. (1967) reported two enzymes with OTCase activity in a strain of Pseudomonas aeruginosa. One of these, assumed to be involved in degradation, has its level increased about threefold in the presence of exogenously supplied arginine $(5 \mathrm{~mm})$. To investigate repression by exogenous arginine in PAOI, it is first necessary to ascertain whether the degradative pathway in strain PAO is significantly induced under the conditions of growth used and to establish valid conditions for assay of the biosynthetic OTCase.

Arginine auxotroph PAO3I 7 which lacks the biosynthetic OTCase function was used to investigate the conditions under which the degradative OTCase is induced. Under some growth conditions, strong induction of this enzyme occurred. Its activity in tris- $\mathrm{HCl}$ buffer was enhanced by phosphate ions ( $4 \mathrm{~mm}$ ) at $\mathrm{pH} 7.5$, but it had no detectable activity at $\mathrm{pH} 8.7$ so that the biosynthetic OTCase could be assayed in its presence. The low basal level of degradative OTCase was not increased by exogenous arginine in strain PAO3I7 growing in shaken, exponential phase cultures.

The effect of exogenous arginine on levels of arginine biosynthetic enzymes in the wild-type organism

The levels of the arginine biosynthetic enzymes $N$-acetyl- $\gamma$-glutamokinase (enzyme 2), $\mathrm{N}$-acetylornithine glutamate transacetylase (enzyme $5^{\prime}$ ), OTCase (enzyme 6) and argininosuccinase (enzyme 8) in Pseudomonas aeruginosa PAOI grown to exponential phase in CMM, and in arginine-supplemented CMM are shown in Table 3. Only the OTCase level was affected, being repressed approximately sixfold at exogenous arginine concentrations greater than $0.3 \mathrm{~mm}$.

The effect on the level of OTCase of growth on arginine as sole carbon source was studied. In PAOI growing exponentially on citrate (IO $\mathrm{mM}$ ) as sole carbon source, the OTCase 
Table 4. The effect of various periods of arginine deprivation in CMM on levels of arginine biosynthetic enzymes in the arginine auxotroph $\mathrm{PAO} 07$

\begin{tabular}{|c|c|}
\hline \multicolumn{2}{|c|}{ Arginine concentration } \\
\hline $\begin{array}{l}\text { Initial } \\
(\mathrm{mm})\end{array}$ & $\begin{array}{c}\text { At } \\
\text { harvesting }\end{array}$ \\
\hline 0.25 & Non-limiting \\
\hline $0 \cdot 25$ & Limiting \\
\hline 0.25 & Limiting \\
\hline
\end{tabular}

Duration of
deprivation
(min)
0
100
450

\begin{tabular}{|c|c|c|c|}
\hline \multicolumn{4}{|c|}{$\begin{array}{c}\text { Enzyme activity } \\
(\mu \mathrm{mol} \mathrm{product} / \mathrm{h} / \mathrm{mg} \text { protein })\end{array}$} \\
\hline \multicolumn{4}{|c|}{$\begin{array}{lllll}2 & 5^{\prime} & 6 & 8\end{array}$} \\
\hline$I \cdot 2$ & $2 \cdot 3$ & 9.0 & \\
\hline$I \cdot 5$ & $2 \cdot 2$ & 10.2 & \\
\hline $1 \cdot 3$ & $2 \cdot 4$ & $10 \cdot 6$ & \\
\hline
\end{tabular}

activity (pH 8.7) was approximately $60 \mu \mathrm{mol} / \mathrm{h} / \mathrm{mg}$ protein. In organisms harvested from citrate medium supplemented with arginine ( $\mathrm{I}$ to $40 \mathrm{mM}$ ) the OTCase activity was substantially diminished to approximately I I $\mu \mathrm{mol} / \mathrm{h} / \mathrm{mg}$ protein. When arginine (Io to $40 \mathrm{mM}$ ) served as the sole carbon source for growth the level of OTCase was further reduced to $0.6 \mu \mathrm{mol} / \mathrm{h} / \mathrm{mg}$ protein.

The effect of limiting exogenous arginine on levels of arginine biosynthetic enzymes in arginine auxotrophs

Arginine auxotrophs required exogenously supplied arginine at I to I.5 mM for nonlimited growth in CMM. Provision of $0.25 \mathrm{mM}$-arginine resulted in cessation of growth of most arginine auxotrophs at a culture density of about 50 Klett units (approximately $10^{8}$ organisms $/ \mathrm{ml}$ ). To investigate the effect of arginine limitation on enzyme levels, organisms were harvested just prior to cessation of growth due to arginine limitation, and at varying times after the cessation of growth. Those organisms which were harvested while growth was still able to occur (at Klett 45-50) were considered not to be experiencing arginine limitation.

The arginine auxotroph, $\mathrm{PAO}_{307}$, was harvested (i) before arginine had limited growth, and (ii) at varying times after growth had ceased due to lack of arginine. The levels of the four arginine biosynthetic enzymes investigated were constant under the different conditions of arginine availability (Table 4). The level of OTCase in the arginine auxotrophs, PA0307, under conditions both of arginine limitation and non-limitation was the same as the partially repressed level found in the wild-type grown in CMM supplemented with arginine. The levels of OTCase in all of the arginine auxotrophs listed in Table $\mathrm{I}$ were found to be between 9 and I I $\mu \mathrm{mol} / \mathrm{h} / \mathrm{mg}$ protein under conditions of either arginine limitation or non-limitation, i.e. they were all within the range of the repressed level of OTCase found in the wild-type organisms grown in CMM.

No increase in enzyme levels under conditions of arginine deprivation was observed in any of the arginine auxotrophs. As derepression involves protein synthesis, the lack of variation in enzyme levels could have been due to an inability to synthesize protein because of lack of arginine. This possibility was examined by the use of slow-growing revertants or bradytrophs (Novick \& Maas, I96I) of arginine auxotrophs, whose growth was limited by the availability of arginine, but which were capable of synthesising protein. A variety of bradytrophs was isolated in order to investigate variations in enzyme levels under different conditions of arginine availability.

Levels of arginine biosynthetic enzymes in bradytrophs grown under arginine limitation

PAOIO3I is a bradytroph isolated following EMS treatment of PAO307. The levels of arginine biosynthetic enzymes of this bradytroph were compared in bacteria grown in CMM 
Table 5. The effect of increased endogenous arginine on OTCase levels in bacteria in exponential phase

$\begin{array}{lcccc}\text { Strain } & \begin{array}{c}\text { Growth } \\ \text { medium }\end{array} & \begin{array}{c}\text { Generation } \\ \text { time (min) }\end{array} & \begin{array}{c}\text { Factor limiting growth } \\ \text { relative to PAOI in CMM }\end{array} & \begin{array}{c}\text { OTCase } \\ \text { activity* }\end{array} \\ \text { PAOI } & \text { CMM } & 55 & & 60 \\ \text { PAOI } & 0.5 \% \text { Glycerol MM } & \text { I20 } & \text { Catabolism of carbon source } & 28 \\ \text { PAOI } & 0.25 \% \text { Glutamate MM } & 110 & \text { Catabolism of carbon source } & 23 \\ \text { PAOI 20: } & \mathrm{CMM}+\mathbf{I} \text { mM-uracil } & 55 & & 55 \\ \text { PAOI 20 } & \mathrm{CMM} & 160 & \text { Pyrimidine biosynthesis } & \text { II }\end{array}$

* OTCase activity was assayed at $\mathrm{pH} 8.7$.

$\dagger$ Glycerol MM $(0.5 \%)$ and glutamate $\mathrm{MM}(0.25 \%)$ were the same as arginine MM except that, instead of arginine as the sole carbon source, they contained $0.5 \%(\mathrm{w} / \mathrm{v})$ glycerol and $0.25 \%(\mathrm{w} / \mathrm{v})$ glutamate (neutralized) respectively.

*. PAOI 20 is a bradytroph derived from PAOI 19 ( $p y r$-5 I) a pyrimidine-requiring mutant (Isaac \& Holloway, I 968).

and in bacteria grown in arginine-supplemented CMM (data included in Table 3). The levels of enzymes 2, $5^{\prime}$ and 8 did not respond to changes in arginine availability. The level of OTCase, however, was increased fivefold under conditions of arginine deprivation, so that the derepressed level attained was the same as that observed in the wild-type strain grown in CMM. Similar results were obtained for PAOI043, PAOI033 and PAOIO36 which are, respectively, bradytrophs of PAO366 (lesion before ornithine), PAO367 (argininosuccinate synthetase) and PAO362 (argininosuccinase). It was possible that the elevated level of OTCase observed in bradytrophs grown in CMM resulted from the selection of back mutants under these growth conditions; but this was excluded by testing cultures for bradytrophy at the time of harvesting.

The inability to demonstrate a higher level of OTCase in bradytrophs than that found in the wild-type in CMM suggests that this ( $60 \mu \mathrm{mol} / \mathrm{h} / \mathrm{mg}$ protein) may be the fully derepressed level. Attempts were therefore made to isolate regulatory mutants with constitutive production of OTCase. The conventional isolation method (Maas, 196I) of selecting clones resistant to the arginine analogue, canavanine, was not possible as PAO in insensitive to concentrations of canavanine up to $2 \mathrm{mg} / \mathrm{ml}$ in either solid or liquid CMM, or, following the method of Calhoun \& Jensen (1972), in fructose minimal medium. Arginine regulatory mutants were also sought unsuccessfully by the method of Jacoby \& Gorini (1967), i.e. by selection for conditionally streptomycin-dependent (CSD) mutants of streptomycin-resistant derivatives of the OTCase mutant PAO3I7.

\section{Response of levels of arginine biosynthetic enzymes to increased endogenous arginine}

The assumption that the level of endogenously produced arginine found in the wild-type grown in CMM does not affect expression of the OTCase structural gene is inherent in the proposal that the OTCase level under these conditions is the fully derepressed level. The effect on the OTCase level of an abnormal increase in the level of endogenous arginine was examined. In strains whose growth rate in exponential phase is limited, relative to the wildtype, by a factor other than arginine availability, accumulation of intracellularly synthesized arginine should result. The effect of this increased endogenous arginine is shown in Table 5 . These data indicate that, above a certain level, endogenous arginine is effective in reducing the level of OTCase. 


\section{DISCUSSION}

The pathway of arginine biosynthesis in Pseudomonas aeruginosa resembles that of Micrococcus glutamicus (Udaka \& Kinoshita, 1958) rather than that of Escherichia coli (Vogel \& Bonner, I956) in that $N$-acetyl- $\gamma$-glutamokinase is effectively the first enzyme. The feedback inhibition of this enzyme in P. aeruginosa by the three products ornithine, citrulline and arginine, provides a mechanism for limiting utilization of glutamate and for decreasing the levels of the other substrates in the pathway. Because of the structural similarity of the three effective compounds, it is likely that they all act, with differing affinities, at the same site on the $N$-acetyl- $\gamma$-glutamokinase molecule.

Repression by arginine occurred only for OTCase and not for the other three enzymes examined. Three different levels of OTCase were demonstrated under varying conditions. The maximum level of about $60 \mu \mathrm{mol} / \mathrm{h} / \mathrm{mg}$ protein occurred in the wild-type strain grown on CMM and also in arginine bradytrophs grown under conditions of arginine limitation. Exogenous arginine in the presence of another carbon source such as citrate resulted in a sixfold repression of OTCase both in the wild-type and in arginine bradytrophs. This level (10 $\mu \mathrm{mol} / \mathrm{h} / \mathrm{mg}$ protein) was also observed under conditions both of arginine excess or deprivation for all arginine auxotrophs (except, of course, the OTCase-deficient mutant PAO3 I 7). Significantly greater repression (I00-fold) occurred with arginine as the sole carbon source.

The level of OTCase in the wild-type in CMM appears to be the fully derepressed level as it is also the level found in arginine bradytrophs with a growth rate severely limited by arginine availability. To confirm this view it will be necessary to isolate regulatory mutants which show constitutive synthesis of OTCase.

Sercarz \& Gorini (1964) reported that for a hybrid strain of Escherichia coli $\mathrm{KI} 2$ and $E$. coli в only exogenous arginine is effective in repression, while endogenous arginine is employed for protein synthesis. They suggested that this represented an extreme case of the normal situation in the parent strains in which there is compartmentalization of endogenous and exogenous arginine but rapid exchange between these compartments. In the mutant hybrid, Sercarz \& Gorini suggested that the route of conversion is blocked, so that exchange between the two compartments can occur only at relatively high levels of exogenous or endogenous arginine.

The apparently fully derepressed level of OTCase observed in the wild-type organism in CMM and the repressed level of OTCase in arginine auxotrophs can be explained if a similar situation exists in Pseudomonas aeruginosa. It appears that the level of endogenous arginine in the wild-type growing in CMM is too low to be effective in repression, but when the growth rate is limited by some other factor, the relative increase of endogenous arginine results in partial repression of OTCase. However, exogenous arginine appears to be effective in repression even at quite low levels. The repressed level of OTCase observed for arginine auxotrophs can be explained if it is assumed that, as the external supply of arginine is depleted below the level effective in repression, these auxotrophs are unable to synthesize protein because of a lack of endogenous arginine. They are therefore unable to respond to arginine deprivation by an increase in enzyme synthesis. Bradytrophs of such mutants, however, which are capable of some endogenous arginine synthesis, respond to arginine limitation by an increase in OTCase synthesis.

The increased repression observed when arginine is present as sole carbon source could be due to an increased intracellular concentration of arginine when it is being utilized as a 
sole carbon source. This may result from increased levels of an inducible permease under these conditions.

The lack of variation in levels of $N$-acetyl- $\gamma$-glutamokinase, $N$-acetylornithine-glutamate transacetylase and argininosuccinase is comparable to the lack of variation of levels of phosphoribosyl anthranilate isomerase in the tryptophan biosynthetic pathway in Pseudomonas putida (Crawford \& Gunsalus, 1966), and of some enzymes involved in pyrimidine biosynthesis (Isaac \& Holloway, 1968) and isoleucine-valine biosynthesis (Marinus \& Loutit, I969) in $P$. aeruginosa. In this respect, the control of arginine biosynthesis in $P$. aeruginosa resembles that reported by Middelhoven (1969) for Saccharomyces cerevisiae in contrast to that found in E. coli $\mathrm{KI} 2$ and Proteus mirabilis for which pathway-wide repression has been demonstrated.

This work was supported by a grant from the Australian Research Grants Committee. We wish to thank Mrs Miriam Wajnstok and Mrs Sue Batterham for competent technical assistance.

\section{REFERENCES}

Albrecht, A. M. \& Vogel, H. J. (I964). Acetylornithine $\delta$-transaminase. Partial purification and repression behaviour. Journal of Biological Chemistry 239, $1872-1876$.

ARCHIBALD, R. M. (I 944). Determination of citrulline and allantoin and demonstration of citrulline in blood plasma. Journal of Biological Chemistry $\mathbf{1 5 6 ,}$ I 2 I-I42.

BAICH, A. \& VogeL, H. J. (I962). $N$-Acetyl- $\gamma$-glutamokinase and $N$-acetyl- $\gamma$-semialdehyde dehydrogenase: Repressible enzymes of arginine synthesis in Escherichia coli. Biochemical and Biophysical Research Communications 7, 49I-496.

Baumberg, S., Bacon, D. F. \& Vogel, H. J. (I965). Individually repressible enzymes specified by clustered genes of arginine synthesis. Proceedings of the National Academy of Sciences of the United States of America 53, 1029-1032.

Calhoun, D. H. \& Jensen, R. A. (I972). The significance of altered carbon flow in aromatic amino acid synthesis: an approach to the isolation of regulatory mutants in Pseudomonas aeruginosa. Journal of Bacteriology (in the Press).

Crawford, I. P. \& Gunsalus, I. C. (1966). Inducibility of tryptophan synthetase in Pseudomonas putida. Proceedings of the National Academy of Sciences of the United States of America 56, 717-724.

Fargie, B. \& Holloway, B. W. (1965). Absence of clustering of functionally related genes in Pseudomonas aeruginosa. Genetical Research 6, 284-299.

Feary, T. W., Williams, B., Calhoun, D. H. \& Walker, T. A. (1969). An analysis of arginine requiring mutants in Pseudomonas aeruginosa. Genetics 62, 673-686.

Gorini, L. \& Gunderson, W. (I96I). Induction by arginine of enzymes of arginine biosynthesis in Escherichia coli в. Proceedings of the National Academy of Sciences of the United States of America 47, 96I-97I.

Hamilton, W. A. \& Dawes, E. A. (1959). A diauxic effect with Pseudomonas aeruginosa. Biochemical Journal 7r, 25 P.

Holloway, B. W. (1969). Genetics of Pseudomonas. Bacteriological Reviews 33, 419-433.

Holloway, B. W., Egan, J. P. \& Monk, M. (1960). Lysogeny in Pseudomonas aeruginosa. Australian Journal of Experimental Biology and Medical Science 38, $32 \mathrm{I}-330$.

IsaAC, J. H. \& HollowaY, B. W. (I968). Control of pyrimidine biosynthesis in Pseudomonas aeruginosa. Journal of Bacteriology 96, I732-174I.

JACOBY, G. A. \& GoRINI, L. (1967). Genetics of the control of the arginine pathway in Escherichia coli B and K. Journal of Molecular Biology 24, 4I-50.

Lowry, D. H., Rosebrough, N. J., Farr, A. L. \& Randall, R. J. (I951). Protein measurement with the Folin phenol reagent. Journal of Biological Chemistry 193, 265-275.

MAas, W. K. (196I). Studies on repression of arginine synthesis in Escherichia coli. Cold Spring Harbor Symposium on Quantitative Biology 26, 183-191.

Marinus, M. G. \& Loutit, J.S. (1969). Regulation of isoleucine-valine biosynthesis in Pseudomonas aeruginosa. II. Regulation of enzyme activity and synthesis. Genetics $\mathbf{6 3}, 557-567$. 
Middelhoven, W. J. (1969). Enzyme repression in the arginine pathway of Saccharomyces cerevisiae. Antonie van Leeuwenhoek 35, 21 5-226.

Novick, R. P. \& MAAS, W. K. (I96I). Control by endogenously synthesized arginine of the formation of ornithine transcarbamylase in Escherichia coli. Journal of Bacteriology 81, 236-240.

PeArCE, L. E. \& Loutrit, J. S. (I965). Biochemical and genetic grouping of is sleucine-valine mutants of Pseudomonas aeruginosa. Journal of Bacteriology 89, 58-63.

Prozesky, O. W. (1967). Arginine synthesis in Proteus mirabilis. Journal of General Microbiology 49, 325-334.

Prozesky, O. W. (1969). Regulation of the arginine pathway in Proteus mirabilis. Journal of General Microbiology 55, 89-IOz.

RATNER, S. (1955). Enzymatic synthesis of arginine (condensing and splitting enzymes). Methods in Enzym$\operatorname{ology} 2,356-359$.

Sercarz, E. E. \& Gorini, L. (1964). Different contribution of exogenous and endogenous arginine to repressor formation. Journal of Molecular Biology 8, 254-262.

Stalon, V., Ramos, F., Piérard, A. \& Wiame, J. M. (1967). The occurrence of a catabolic and an anabolic ornithine carbamoyl transferase in Pseudomonas. Biochimica et biophysica acta 139, 91-97.

Udaka, S. (1966). Pathway-specific pattern of control of arginine biosynthesis in bacteria. Journal of Bacteriology 91, 617-62I.

UdAKA, S. \& Kinoshita, S. (1958). Studies on L-ornithine fermentation. I. The biosynthetic pathway of L-ornithine in Micrococcus glutamicus. Journal of General and Applied Microbiology 4, 272-282.

VoGEL, H. J., BACON, D. F. \& BAICH, A. (I963). Induction of acetylornithine $\delta$-transaminase during pathway wide repression. In Informational Macromolecules, pp. 293-300. Edited by H. J. Vogel, V. Bryson and J. O. Lampen. New York: Academic Press.

VogeL, H. J. \& BonNer, D. M. (1956). Acetylornithinase of Escherichia coli: partial purification and some properties. Journal of Biological Chemistry 218, 97-106. 